ORIGINAL RESEARCH ARTICLE

\title{
Impact of dye effluent on growth and chlorophyll content of Alfalfa (Medicago sativa L.) \\ Pratibha Mahawar $^{1 *}$ and Azra Akhtar ${ }^{2}$
}

${ }^{1}$ Research Scholar, Department of Botany, Government College, Kota, Rajasthan, India.

${ }^{2}$ Lecturer, Department of Botany, Government College, Kota, Rajasthan, India.

Received: September 3, 2016; Accepted: September 17, 2016

\begin{abstract}
The textile industry plays an important role in the world economy as well as in our daily life time, it consumes large quantity of water and generates huge amount of waste water. The chemical reagents used in the textile sector are diverse in chemical composition ranging from inorganic to organic molecules. The presence of these chemicals will show detrimental effects on the germination process and growth of seedlings. Present research work has been carried out to study the impact of effluent at different concentrations $(20 \%, 40 \%, 60 \%, 80 \%, 100 \%)$ on seed germination and seedling growth of Medicago sativa. On the $14^{\text {th }}$ day of seedling growth, maximum root and shoot length were observed at $20 \%$ concentration of effluent i.e. $5.4 \mathrm{~cm}$ (root length) and $5.1 \mathrm{~cm}$ (shoot length) which increased $3.8 \%$ and $4.0 \%$ respectively in comparison to control. At high concentrations of treatment levels root length was decreased $2.04 \%, 19.2 \%$, $26.5 \%, 51.0 \%$ respectively and shoot length was decreased $3.84 \%, 17.3 \%, 26.9 \%, 44.2 \%$ respectively at $40 \%$, $60 \%, 80 \%$ and $100 \%$ treatment levels in comparison to control $(4.9 \mathrm{~cm}$ and $5.2 \mathrm{~cm}$ respectively). Same trend was observed during estimation of dry weight and chlorophyll contents. Inhibition of seedling germination and seedling growth at higher concentrations of effluent may be due to high level of dissolved solids which inhance the salinity. The present study concluded that the dyeing effluent waste significantly influence growth parameters of Medicago sativa.
\end{abstract}

Key words: Medicago sativa; textile dye effluent; germination; seedling growth; chlorophyll contents

\section{Introduction}

Dying and printing industries are one of the most water consuming industries, responsible for water and soil pollution. These industries constantly adding up toxic substances in to the ground water reservoir in the industrial zone and used for irrigation. These toxic substances can be transferred and get accumulated into plant tissues from soil and have damaging effects on plant themselves and may become a health problem to man and animals (Garg et al., 2007). Wynne et al., (2001) noted that textile effluent is highly colored and saline contain nonbiodegradable compounds and are high in biological oxygen demand (BOD), chemical oxygen demand (COD), sodium and other dissolved solids as well as micronutrients and heavy metals (Martin et al., 1994). These effluents cause coloration of water when released untreated into the water bodies and cause severe problems to aquatic life (Hai et al., 2007). The use of such waste water in irrigation system definitely provides some nutrients to enhance the fertility of soil properties in the long run (Yasmin et al., 2011). Accumulation of excessive salts makes the soil saline, while presences of excessive color in effluent pollutes the water bodies and prevent the penetration of light, which in turn impedes with the photosynthetic activities of aquatic flora (Ranganathan and Kurian, 1997). Many scientists

\section{${ }^{*}$ Corresponding Author:}

\section{Pratibha Mahawar}

Research scholar,

Department of Botany, Government College,

Kota, Rajasthan, India.

E- mail: mahawar.pratibha@gmail.com have documented adverse effects of different industrial effluents on the growth of plants and dye waste water has also been found toxic to several crop plants (Kaushik et al., 2005, Sundaramoorthy et al., 2001). Malaviya et al., (2012) demonstrated that at lower concentration of dying and industrial effluent cause a positive impact on germination and growth of Pisum sativum. At 100\% effluent concentration nutrients were raised to high to become toxic resulting in retarded root and shoot length. Germination of seed is a critical stage which insures reproduction and consequently the control of dynamic population to it at least for proper crop productivity. Hence considering all the good and bad effects of industrial effluents on crop plants, the present study was conducted by using effluents obtained from dying and printing industry as a source of water to germinate seedling of Medicago sativa and its effect was observed on growth and chlorophyll content.

\section{Materials and Methods \\ Experimental Plant}

Alfalfa (Medicago sativa L.) is the most cultivated forage legume in the world due to its high nutritional quality, high protein content and effects on soil fertility. It has played an important role as a livestock forage. The medicinal uses of alfalfa stem 
from anecdotal reports that the leaves causes dieresis and are useful in the treatment of kidney, bladder and prostate disorders. Its extracts are used in baked goods, beverages, and prepared foods and the plant serves as a commercial source of chlorophyll.

\section{Collection of Effluent sample}

The effluent samples were collected from small dying and printing units from kaithun region, Kota, Rajasthan. Samples were collected in sterilized wide mouth poly ethylene bottles and were stored at $4^{\circ} \mathrm{C}$ temperature to avoid any changes on its characteristics. To evaluate the effects of dyeing effluent on Medicago sativa, solution of different concentrations of effluent were prepared.

\section{Treatment Level}

C- Control (100\% Distilled water)

$\mathrm{T}_{1}$ - Effluent: Distilled water $(20 \%+80 \%)$

$\mathrm{T}_{2}$ - Effluent: Distilled water $(40 \%+60 \%)$

$\mathrm{T}_{3}$ - Effluent: Distilled water $(60 \%+40 \%)$

$\mathrm{T}_{4}$ - Effluent: Distilled water $(80 \%+20 \%)$

$\mathrm{T}_{5}$ - Effluent $(100 \%)$

For germination tests, seeds were sterilized with $0.1 \% \mathrm{w} / \mathrm{v}$ mercuric chloride $\left(\mathrm{Hgcl}_{2}\right)$ solution for 5 minutes to remove microbes and then washed three times with sterile distilled water. 20 seeds of Alfalfa were placed in sterilized glass petri dishes of uniform size lined with filter paper discs. These filter discs were then moistened with $5 \mathrm{ml}$ of distilled water for control and with the same quantity of various concentrations of the textile effluent $(20 \%, 40 \%, 60 \%, 80 \%, 100 \%)$. The Petri dishes were incubated at room temperature. $2 \mathrm{ml}$ of respective dilutions were sprayed for consecutive 6 days. Germination was recorded daily. All the levels were carried out in triplicate. On the $7^{\text {th }}$ day, germination percentage was calculated and various growth parameters and chlorophyll content were evaluated on $14^{\text {th }}$ day of the experiment.

\section{Germination percentage}

The formula given by Rehman et al., (1998) was used to estimate germination percentage.

$$
\begin{aligned}
\text { No. of seeds germinated } & \\
\text { Germination percentage } & =\ldots \ldots \ldots \ldots \ldots \ldots \ldots . \ldots 10 \\
& \text { Total no. of seeds }
\end{aligned}
$$

\section{Root and Shoot length}

Length of root and shoot of seedlings were calculated by using the standard centimeter scale.

\section{Vigour index}

The formula suggested by Abdul-Baki and Anderson (1973) was used to calculate vigour index. Vigour index = germination percentage' (root length* + shoot length*)

(* indicate that length of root and shoot in $\mathrm{cm}$.)

\section{Fresh and Dry Weight of seeds}

Ten seeds of each treatment were weighted in order to determine the fresh weight and then dried in oven at $80^{\circ} \mathrm{C}$ for $24 \mathrm{hrs}$. to obtain dry weight. Fresh weight and Dry weight were recorded in gms.

\section{Chlorophyll estimation}

The estimation of chlorophyll content was done according to Arnon's method (1949).

$$
\begin{gathered}
\text { Chlorophyll a (mg/g) }=\begin{array}{c}
12.7 \mathrm{~A}_{663}-2.69 \mathrm{~A}_{645} \\
\mathrm{~A} \times 1000 \times \mathrm{W}
\end{array} \\
\begin{array}{c}
22.9 \mathrm{~A}_{645}-4.68 \mathrm{~A}_{663} \\
\text { Chlorophyll B }(\mathrm{mg} / \mathrm{g})
\end{array} \\
\mathrm{A} \times 1000 \times \mathrm{W}
\end{gathered}
$$

Where

$\mathrm{A}_{663}=$ Absorbance at wavelength $663 \mathrm{~nm}$ $\mathrm{A}_{645}=$ Absorbance at wavelength $645 \mathrm{~nm}$ $\mathrm{V}=$ Volume of the extract in $\mathrm{ml}$ $A=$ Length of light path in the cuvette $(1 \mathrm{~cm})$ $\mathrm{W}=$ Fresh weight of the samples in $\mathrm{gm}$.

\section{Result and Discussion}

The present study was carried out to assess the effect of dying industry effluent on germination and seedlings growth to determine the tolerance level of Alfalfa (Medicago sativa). The result revealed that Medicago sativa shows positive growth response to the dying effluent at treatment level $\mathrm{T}_{1}(20 \%$ Effluent $+80 \% \mathrm{D} / \mathrm{w})$. Seedling growth showed increase in shoot and root lengths at $\mathrm{T}_{1}$ whereas a gradual decline was observed in growth parameters with the increasing concentration of dying effluent at levels $\mathrm{T}_{2}-\mathrm{T}_{5}(40 \%, 60 \%, 80 \%, 100 \%)$. In the present study at $20 \%$ concentration of effluent the seedling growth showed maximum root length $5.4 \mathrm{~cm}$ and shoot length $5.1 \mathrm{~cm}$ i.e. $3.8 \%$ and $4.0 \%$ in comparison to control but at high concentrations of treatment level $(40 \%, 60 \%, 80 \%, 100 \%)$ root length was decreased $2.04 \%, \quad 19.2 \%, \quad 26.5 \%, \quad 51.0 \%$ respectively and shoot length was decreased 3.84\%, $17.3 \%, 26.9 \%, 44.2 \%$ respectively in comparison to control. Other parameters were also decreased at higher concentrations of effluent. Values of various parameters for different concentrations of the effluent are given in table 1. 
Table 1: Effect of different concentrations of effluent on various parameters of Medicago sativa

\begin{tabular}{|c|c|c|c|c|c|c|c|c|c|}
\hline S.No. & Treatment & $\begin{array}{c}\text { Seed } \\
\text { germination } \\
\text { Percentage } \\
\text { (7th Days) }\end{array}$ & $\begin{array}{l}\text { Vigour } \\
\text { Index }\end{array}$ & \multicolumn{2}{|c|}{$\begin{array}{l}\text { Seedling Growth } \\
\left.\text { (14 }{ }^{\text {th }} \text { Days }\right)\end{array}$} & \multicolumn{2}{|c|}{ Weight } & \multicolumn{2}{|c|}{$\begin{array}{l}\text { Chlorophyll content } \\
(\mathrm{mg} / \mathrm{gm})\end{array}$} \\
\hline \multirow[t]{2}{*}{1.} & Control & $83 \%$ & 838.3 & 4.9 & 5.2 & 1.57 & 0.51 & 3.02 & 2.96 \\
\hline & & & 945 & 5.1 & 5.4 & 1.77 & 0.57 & 3.21 & 3.01 \\
\hline 2. & $20 \%$ & $90 \%$ & $(12.7 \%)^{* *}$ & $(4.0 \%)^{* *}$ & $(3.8 \%)^{* *}$ & $(12.7 \%)^{* *}$ & $(11.7 \%)^{* *}$ & $(6.2 \%)^{* *}$ & $(1.6 \%)^{* *}$ \\
\hline 3. & & & 504 & 4.1 & 4.3 & 1.39 & 0.42 & 2.03 & 2.56 \\
\hline \multirow[t]{2}{*}{4.} & $60 \%$ & $66 \%$ & $(33.8 \%)^{*}$ & $(19.2 \%)^{*}$ & $(17.3 \%)^{*}$ & $(11.4 \%)^{*}$ & $(17.6 \%)^{*}$ & $(32.7 \%)^{*}$ & $(13.5 \%)^{*}$ \\
\hline & & & 370 & 3.6 & 3.8 & 0.95 & 0.35 & 1.92 & 1.80 \\
\hline \multirow[t]{2}{*}{5.} & $80 \%$ & $50 \%$ & $(55.8 \%)^{*}$ & $(26.5 \%)^{*}$ & $(26.9 \%)^{*}$ & $(39.4 \%)^{*}$ & $(31.3 \%)^{*}$ & $(36.4 \%)^{*}$ & $(39.1 \%)^{*}$ \\
\hline & & & 174.9 & 2.4 & 2.9 & 0.52 & 0.22 & 1.01 & 1.05 \\
\hline 6. & $100 \%$ & $33 \%$ & $(79.1 \%)^{*}$ & $(51.0 \%)^{*}$ & $(44.2 \%)^{*}$ & $(66.8 \%)^{*}$ & $(56.8 \%)^{*}$ & $(66.5 \%)^{*}$ & $(64.5 \%)^{*}$ \\
\hline
\end{tabular}

$*$ Figures in parentheses represent $\%$ decrease over control.

**Figures in parentheses represent $\%$ increase over control.

From the experimental data it has been revealed that in Medicago sativa suppression of germination, shoot and root lengths and chlorophyll contents (chl.a and chl.b) were affected at higher concentration (above $40 \%$ ) of effluent may be due to high levels of total dissolved soilds which enhance the salinity and conductivity of the solute absorbed by the seeds before germination. Our findings are also in accordance with the outcome obtained by Wins et al., (2010) who investigated that at $25 \%$ concentration along with the growth promoting effect, significantly better than control. Beyond 25\% effluent, root and shoot length decreased. Similar results were made by Lenin et al., (2014) who reported that the best germination of seedling growth, root length, shoot length, fresh weight and dry weight and tolerant variety were observed with $20 \%$ effluent concentration of sago factory effluent with growth promoting effect significantly better than control. Beyond 20\% effluent concentration, root and shoot length were reportedly decreased. The same trend was observed by Mohammad and Khan (1985) while studying the effect of textile industry effluent and they found that no adverse effect of textile industry effluent at lower concentration $(<50 \%$ effluent concentration) which is in conformity with the present results. Present study also supports the view of Chinnusamy et al., (2001) who observed that root length, shoot length, fresh weight root and shoot, dry weight of root and shoot, germination relative index, vigour index and chlorophyll content were higher in $25 \%$ than $50 \%$ over control. It also supported by Parameswari M. (2014) who reported that concentrated textile and dying effluent adversely affect the crop plants, although diluted textile and dye effluent with water in 1:3 ratio did not have any adverse effect on the growth and vigour index of field crops and the diluted effluent increased the germination and vigour index of groundnut.

In this paper an attempt has been made to assess the effect of textile and dying effluent on germination and seedling growth of Alfalfa
(Medicago sativa). Present study concluded that seed germination percentage, vigour index, root and shoot length, fresh and dry weight and chlorophyll content were higher in lower effluent concentration $(20 \%$ effluent) but decrease with the increasing concentration of effluent $(40 \%, 60 \%, 80 \%, 100 \%)$.
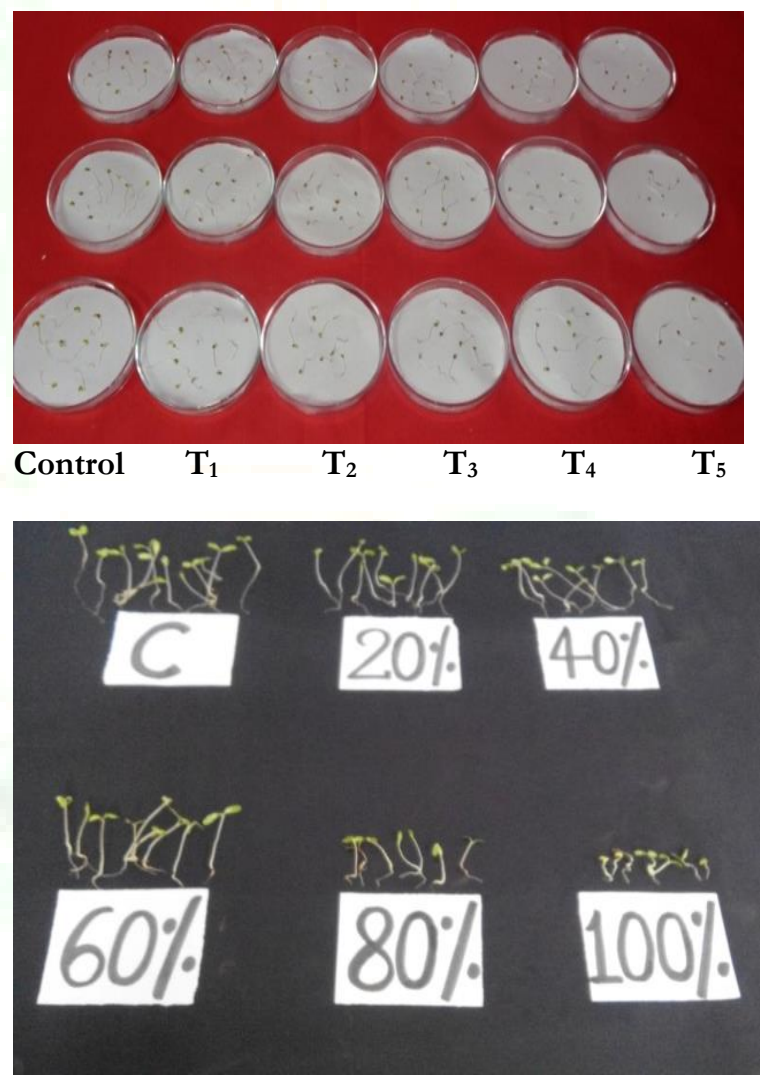

Fig. $14^{\text {th }}$ day germination state in Madicago sativa L.

\section{References}

1. Abdul Baki A.A. and Anderson, J.D. Vigour determination of soybean seeds by multiply criteria. Crop, sci., 1973. Vol. 13: 630-633.

2. Arnon, D.I. Copper enzymes in isolated chloroplasts. Polyphenoloxidase in Beta vulgaris. Plant Physiol., 1949. Vol. 24: 1-15. 
3. Chinnusamy, Annadurai C. K., Jayanthi C., Veetaputhrian R. and Karunanthi S. Organic amendments and distillery effluent on soil fertility and productivity of rice. Proceedings of National Seminar on Use of Poor Quality Water and Sugar Industrial Effluents in Agriculture, 2001 Feb. 5, TNAU, Tiruchirapalli, 84-84.

4. Garg V.K., Kaushik P. Influence of textile mill waste water irrigation on the growth of Sorghum cultivars. Applied ecology and environmental research, 2007, 6(2), 1-12.

5. Hai, F.I., K. Yamamoto and K. Fukushi. Hybrid treatment systems for dye wastewater. Critical Rev. Environ. Sci. Technol., 2007, 37, 315-377.

6. Kaushik P., Garg V.K., Singh B. Effect of textile effluent on different cultivar of wheat. Biores. Technol., 2005, 96, 1189-1193.

7. Lenin M., Mariyappan K.S. and Thamarikannan M.R. Effect of sago factory effluent on seed germination and seedling growth of gingelly (sesamum indicum L.) varieties. Int. J. Life Sc. Bt. \& Pharm. Res., 2014, 3(1), 2250-3137.

8. Malaviya P., Rajesh H., Neeru S. Impact of dyeing industry effluent on germination and growth of pea (Pisum sativum). J. Environ. Biol., 2012, 33, 1075-1078.

9. Martin M.H. and Bullock R.J. The impact and fate of heavy metals in an Oak woodland ecosystem. In: M. Ross(ed): Toxic metals in soilplant system, 1994. John wiley \& sons, New York. 327-363.

10. Mohammad A., Khan AA.U.. Effect of textile factory effluent on soil and crop plants. Environ. Pollun., 1985. (Series A), 37, 131-148.

11. Parameswari M. Effect of textile and dye effluent irrigation on germination and its growth parameters of green gram, black gram and red gram. International journal of environmental science and toxicology research 2014, 2(1), 6-10.

12. Ranganathan KM, Kurian J. Industrial effluent management for clusters of textile bleaching and dying units. Proc. $6^{\text {th }}$ Natl. Symp. On Environ., 1997 Coimbatore, 84-88.

13. Rehman S., Harris P.J.C. and Bourne W.P. Effect of pre-sowing treatment with calcium salts. Acacia seeds, J. Plant nutrition, 1998, 21, 277-285.

14. Sundaramoorthy P., Kunchithapatam J., Thamizhiniyan P. and Venkateslu V. Effect of fertilizer factory effluent on germination and seedling growth of groundnut varieties. J. Ecobiol.,2001, 13(1), 03-08.

15. Wins. J.A. And Murugan M. Effect of textile mill effluent on growth and germination of Black gram Vigna munga (L.) Hepper. Int. J. Pharma. Biosci., 2010, 1, 1-7.

16. Wynne G., Maharaj D. and Buckley C. Cleaner production in the textile industry. Lessons from the Danish experience, school of chemical engineering, 2001. University of Natal, Durban, South Africa, 3.

17. Yasmin A., Nawaz S and Ali S. M. Impact of industrial effluents on germination and seedling growth of Lens Esculentum varieties. Pak. J. Bot., 2011, 43(6), 2759-2763.

\section{Cite this article as:}

Pratibha Mahawar and Azra Akhtar. Impact of dye effluent on growth and chlorophyll content of Alfalfa (Medicago sativa L.). Annals of Plant Sciences 5.9 (2016): 1432-1435.

DOI: http://dx.doi.org/10.21746/aps.2016.10.004

Source of support: Nil.

Conflict of interest: None Declared 